\title{
PENGARUH EDUKASI GIZI MENGGUNAKAN MEDIA BUKU CERITA BERGAMBAR TERHADAP PERUBAHAN KONSUMSI BUAH DAN SAYUR ANAK DI PAUD CEMARA, SEMARANG
}

\author{
Gisi Sari Bestari, Adriyan Pramono*) \\ Program Studi Ilmu Gizi Fakultas Kedokteran Universitas Diponegoro \\ Jl.Dr.Sutomo No.18, Semarang, Telp (024) 8453708, Email : gizifk@ undip.ac.id
}

\begin{abstract}
Background: Low consumption of fruit and vegetable is a major child eating behavior problems that commonly found. One of the dominant factors to resolved this problem is repeated exposure to fruit and vegetable. It takes parents and teacher support and motivation so that children's fruit and vegetable intake may persist into adulthood. Nutrition education using illustrated story book media is one of Entertainment Education (EE) form which can be used as an effective media to increase children's fruit and vegetable intake while allowing direct interaction of children and parents or teacher. EE method development in Indonesia can be expected as a solution to overcome the low consumption of fruits and vegetables in children.

Method: Pre-experimental one group with pre-post test design was conducted on 18 students of PAUD Cemara, Semarang who are determined based on inclusion criteria. Nutrition education using illustrated story book, was performed by the Teachers in 8 sessions. After education was conducted, 8 times of fruits and vegetable snack were given to control the availability variable of fruit and vegetable. Seven day daily food record and child eating behavior questionnaire was taken to assess changes in children's consumption of fruit and vegetables before and after treatment.

Results: There is no significant difference between energy, fiber, type and amount of vegetable, and type and amount of fruit variable before and after treatment $(p \geq 0.05)$. There is no significant difference in children fruit and vegetable consumption behavior before and after treatment $(p \geq 0.05)$.

Conclusion: Nutrition education using illustrated story books media lead to increased children fruit and vegetable consumption, but not significant.
\end{abstract}

Keyword: nutrition education; illustrated story books; children fruit and vegetable consumption

\section{ABSTRAK}

Latar belakang: Konsumsi buah dan sayur yang rendah masih merupakan masalah perilaku makan anak yang paling sering ditemukan. Salah satu faktor dominan dalam meningkatkan konsumsi buah dan sayur anak adalah adanya paparan buah dan sayur yang berulang. Dibutuhkan dukungan dan motivasi orang tua dan guru yang sangat kuat agar peningkatan asupan buah dan sayur anak dapat bertahan hingga dewasa. Edukasi gizi menggunakan media buku cerita bergambar merupakan salah satu bentuk Entertainment Education (EE) yang dapat digunakan sebagai salah satu cara peningkatan asupan buah dan sayur anak sekaligus memungkinkan interaksi langsung anak dan orang tua. Pengembangan metode EE di Indonesia diharapkan dapat mengatasi permasalahan rendahnya konsumsi buah dan sayur anak.

Metode: Desain pra eksperimen satu kelompok perlakuan dengan tes sebelum dan sesudah perlakuan dilakukan pada subyek 18 siswa PAUD Cemara yang ditentukan berdasarkan kriteria inklusi. Perlakuan berupa edukasi gizi menggunakan buku cerita bergambar oleh guru PAUD Cemara selama 8 kali pertemuan. Sejumlah 8 kali snack buah dan sayur diberikan untuk mengontrol variabel ketersediaan buah dan sayur. Catatan konsumsi makanan selama 7 hari dan kuesioner perilaku makan anak diambil untuk menilai perubahan konsumsi buah dan sayur anak sebelum dan sesudah perlakuan.

Hasil: Tidak ditemukan beda yang bermakna antara variabel jumlah energi, serat, jenis dan jumlah sayur, serta jenis dan jumlah buah yang dikonsumsi sebelum dan setelah perlakuan ( $p \geq 0.05)$. Tidak ada perbedaan perilaku konsumsi buah dan sayur anak sebelum dan setelah perlakuan $(p \geq 0.05)$.

Simpulan: Edukasi gizi menggunakan media buku cerita bergambar menyebabkan peningkatan konsumsi buah dan sayur anak, namun tidak signifikan.

Kata Kunci: edukasi gizi; buku cerita bergambar; konsumsi buah dan sayur anak

\section{PENDAHULUAN}

Konsumsi buah dan sayur yang rendah masih merupakan masalah utama pada perilaku makan anak yang paling sering ditemukan. ${ }^{1,2}$ Menurut survei konsumsi buah dan sayur nasional pada tahun
2007 sampai 2013, ditemukan bahwa rata-rata konsumsi buah terus menurun dari $49 \mathrm{kkal} / \mathrm{hari}$ menjadi $30 \mathrm{kkal} / \mathrm{hari}$ dan $46 \mathrm{kkal} / \mathrm{hari}$ menjadi 38 $\mathrm{kkal} / \mathrm{hari}$ untuk konsumsi sayur. Sedangkan asupan kalori dari sumber lemak dan minyak terus tinggi 
melebihi batas kecukupan gizi. ${ }^{3}$ Padahal asupan buah dan sayur yang cukup sangat penting terutama pada masa anak-anak. ${ }^{4}$

Konsumsi buah dan sayur secara berulang dan terus menerus merupakan salah satu faktor yang paling dominan dalam usaha meningkatkan konsumsi buah dan sayur anak. ${ }^{5}$ Faktor ini melibatkan aspek ketersediaan dan aksesibiltas buah dan sayur, dukungan orang-orang disekitar anak, serta faktor internal dalam diri anak. ${ }^{6}$ Dilihat dari aspek ketersediaan, produksi sayur yang terus meningkat setiap tahun menjamin ketersediaan sayur ditingkat pasar. Sedangkan produksi buah yang menurun sejak tahun 2009 tidak menyebabkan kelangkaan, yang berarti ketersediaan buah ditingkat pasar juga terjamin. ${ }^{7}$ Namun, dari total rata-rata pengeluaran penduduk untuk makanan, hanya $9,8 \%$ pengeluaran dibelanjakan untuk membeli sayur dan hanya 5,4\% dibelanjakan untuk membeli buah. ${ }^{8}$ Data ini dapat berarti ketersediaan buah dan sayur di tingkat rumah tangga masih rendah. Kondisi ini kemungkinan dapat disebabkan karena harga buah atau sayur yang tinggi sehingga tidak aksesibel, atau dikarenakan pengetahuan dan motivasi orang tua untuk mengkonsumsi buah dan sayur masih rendah.

Konsumsi buah dan sayur anak memang berhubungan dengan tingkat pengetahuan dan motivasi orang tua. Anak-anak sangat tergantung pada orang tua dan guru dalam hal perilaku makan, termasuk memilih makanan kesukaan dan keinginan untuk mencoba makanan baru. ${ }^{9} \mathrm{Hal}$ ini berarti orang tua dan guru memiliki peran yang sangat dominan dalam mendukung konsumsi buah dan sayur anak. Namun, faktor internal yang ada pada diri anak juga merupakan aspek yang tidak dapat dikesampingkan. Anak-anak memiliki faktor internal yang berupa kesukaan terhadap rasa manis, pengetahuan dan persepsi terhadap makanan, serta adanya respon neufobia. ${ }^{9,10,11,12}$ Faktor internal tersebut dapat dirubah dan dibentuk melalui konsumsi buah dan sayur yang berulang. Konsumsi buah dan sayur yang berulang dapat tercapai jika pengetahuan anak tentang pentingnya konsumsi buah dan sayur baik, buah dan sayur tersedia dan orang tua memiliki motivasi dan pengetahuan tentang pentingnya menyediakan buah dan sayur di rumah.

Edukasi gizi menggunakan media buku cerita bergambar atau sering disebut sebagai bentuk Entertainment Education (EE) merupakan salah satu metode peningkatan konsumsi buah dan sayur anak yang banyak dikembangkan di Eropa. Metode ini selain diketahui secara efektif dapat meningkatkan pengetahuan dan kesukaan anak terhadap buah dan sayur, juga memungkinkan interaksi langsung antara orang tua atau guru dengan anak melalui kegiatan mendengar aktif cerita. ${ }^{13}$ Beberapa penelitian terkini menyebutkan bahwa penerapan EE pada anak pra sekolah secara efektif dapat mempengaruhi pengetahuan, sikap, dan perilaku anak terhadap konsumsi buah dan sayur. ${ }^{14,15,16}$ Sejumlah 8 sampai 12 kali paparan berulang diperlukan untuk merubah kebiasaan makan anak. ${ }^{9,17,18}$

Penerapan EE sebagai media untuk meningkatkan asupan buah dan sayur anak belum banyak dikembangkan di Indonesia. Penelitian kali ini menggunakan buku cerita bergambar sebagai media EE untuk meningkatkan pengetahuan dan persepsi anak terhadap buah dan sayur yang dikonsumsi. Sebanyak 8 kali paparan buah dan sayur disediakan oleh peneliti untuk menjamin konsumsi buah dan sayur anak selama intervensi.

\section{METODE PENELITIAN}

Penelitian ini termasuk dalam lingkup keilmuan gizi masyarakat menggunakan desain pra experiment one groups pre-post test design. Populasi dalam penelitian ini adalah semua siswa PAUD Cemara, Semarang. Besar sampel yang digunakan dalam intervensi sebanyak 18 orang siswa dengan orang tua atau wali siswa sebagai responden. Kriteria inklusi adalah siswa PAUD Cemara berusia 2 sampai 5 tahun yang orang tuanya bersedia menandatangani informed consent. Kriteria eksklusi adalah subjek pindah atau putus sekolah saat penelitian berlangsung, siswa menderita sakit infeksi, pasca operasi, atau sedang menderita kondisi patologis lain dalam jangka waktu panjang, serta siswa sedang menjalankan perawatan medis dan mengkonsumsi obat-obatan dalam jangka panjang.

Variabel tergantung pada penelitian ini adalah perubahan perilaku makan dan konsumsi buah dan sayur setelah intervensi. Variabel bebas pada penelitian ini adalah edukasi gizi menggunakan media buku cerita bergambar. Pemilihan subyek penelitian, dan wawancara kuesioner perilaku makan buah dan sayur anak dilakukan selama satu hari pada tanggal 4 Agustus 2014. Setiap responden dari subyek terpilih diberikan informed consent sebagai tanda subyek setuju ikut serta dalam penelitian, sementara pembuatan ethical clearance diajukan kepada Komite Etik Penelitian Fakultas Kedokteran Universitas Diponegoro/RSUP Dr Kariadi Semarang.

Pengukuran antropometri dilakukan untuk mengetahui status gizi subyek. Berat badan diukur 
menggunakan timbangan berat badan dengan ketelitian $0,1 \quad \mathrm{~kg}$. Tinggi badan diukur menggunakan microtoise dengan ketelitian $0,1 \mathrm{~cm}$. Hasil pengukuran kemudian di plot kan pada kurva $z$-score WHO untuk anak usia 2-5 tahun berdasarkan berat badan terhadap tinggi badan. Hasil pengukuran dikelompokkan menjadi kategori status gizi lebih jika $>3 \mathrm{SD}$, status gizi normal jika $2 \mathrm{SD} \leq \mathrm{s} / \mathrm{d} \leq-2 \mathrm{SD}$, dan status gizi kurang jika $<-3$ SD.

Intervensi berupa edukasi gizi menggunakan media buku cerita bergambar dilakukan oleh guru PAUD Cemara, Semarang sebanyak 8 kali cerita selama 4 minggu. Setiap pertemuan, dibacakan 2 bab cerita yang dilakukan oleh guru yang sama selama 15 menit. Guru memberikan beberapa pertanyaan tentang cerita yang bersifat memancing rasa ingin tahu dan menguji tingkat pemahaman anak pada awal, pertengahan, dan akhir cerita dibacakan. Bagian yang berisi tentang pesan makan buah dan sayur diulang sebanyak tiga kali pengulangan agar anak mendapatkan inti pesan cerita. Tokoh utama cerita berupa kelinci yang gemar makan sayur dan buah. Setelah cerita dibacakan, anak diberikan makanan ringan dari buah dan sayur seperti yang dikonsumsi tokoh cerita, pada waktu istirahat. Pemberian makanan ringan bertujuan untuk memastikan anak terpapar buah dan sayur minimal 8 kali. Setiap hari dilakukan evaluasi. Hanya subyek yang mendapatkan 8 kali intervensi dan minimal 8 kali terpapar buah dan sayur yang dilakukan evaluasi. Untuk mengetahui adanya perubahan konsumsi buah dan sayur sebelum dan setelah edukasi gizi, dilakukan pengukuran konsumsi buah dan sayur anak selama 7 hari menggunakan instrumen Seven Day Daily Food Record yang meliputi jumlah, jenis, dan cara pengolahan buah dan sayur. Sedangkan perilaku makan anak sebelum dan setelah edukasi gizi diukur menggunakan instrumen Kuesioner Perilaku Makan Anak (Child Eating Behavior Questionnaire/CEBQ).

Pengolahan dan analisis data menggunakan program komputer. Analisis univariat digunakan untuk mengetahui karakteristik subyek penelitian. Pengujian distribusi data dilakukan dengan uji Saphiro-Wilk untuk mengetahui normalitas data. Analisis bivariat menggunakan uji paired t-test untuk mengetahui beda asupan buah dan sayur subyek sebelum dan sesudah intervensi. Uji ini juga digunakan untuk mengetahui beda perilaku konsumsi buah dan sayur subyek.

\section{HASIL PENELITIAN \\ Karakteristik Subyek}

Penelitian ini melibatkan 18 subyek yang terdiri dari 55,6\% anak laki-laki dan 44,4\% anak perempuan berusia 2-4 tahun. Responden penelitian terdiri dari, ibu, nenek, atau pengasuh subyek yang setiap hari mengetahui perilaku makan subyek secara langsung. Sebanyak $88,9 \%$ ayah dan $83,3 \%$ ibu subyek berpendidikan minimum SMA, dan $88,9 \%$ orang tua subyek berpenghasilan lebih dari sama dengan Upah Minimum Rerata (UMR) Kota Semarang. sebanyak $94,4 \%$ siswa memiliki status gizi normal, dan hanya 5,6\% subyek yang memiliki status gizi lebih. Jumlah subyek laki-laki dan perempuan relatif seimbang. Variabel penghasilan dan pendidikan orang tua juga relatif homogen.

Tabel 1. Karakteristik Subyek

\begin{tabular}{lc}
\hline \multicolumn{1}{c}{ Variabel } & Jumlah \\
\hline Total & $\mathrm{n}=18$ \\
Jenis Kelamin & $55.6(\mathrm{n}=10)$ \\
$\quad$ Laki-laki & $44.4(\mathrm{n}=8)$ \\
$\quad$ Perempuan & \\
\hline Pendidikan Ayah & $5.6(\mathrm{n}=1)$ \\
SD & $5.6(\mathrm{n}=1)$ \\
SMP & $33.3(\mathrm{n}=6)$ \\
SMA & $55.6(\mathrm{n}=10)$ \\
Diploma/S1/S2/S3 & \\
\hline Pendidikan Ibu & $5.6(\mathrm{n}=1)$ \\
SD & $11.1(\mathrm{n}=2)$ \\
SMP & $33.3(\mathrm{n}=6)$ \\
SMA & $50(\mathrm{n}=9)$ \\
Diploma/S1/S2/S3 & $11.1(\mathrm{n}=2)$ \\
\hline Penghasilan Orang Tua & $88.9(\mathrm{n}=16)$ \\
$\quad$ U UMR & \\
$\geq$ UMR & $5,6 \%(\mathrm{n}=1)$ \\
\hline Status Gizi Responden & $94.4 \%(\mathrm{n}=17)$ \\
$\quad$ Lebih &
\end{tabular}

*UMR $=$ Upah Minimum Rerata Kota Semarang tahun 2014 Rp 1.220.000, 00 


\section{Beda Asupan Buah dan Sayur Sesudah dan Sebelum Intervensi}

Dalam uji normalitas data, ditemukan bahwa data berdistribusi normal. Hasil uji beda dipaparkan dalam Tabel 2.

Tabel 2. Asupan Buah dan Sayur

\begin{tabular}{|c|c|c|c|c|c|}
\hline Variabel & $\mathbf{N}$ & Mean \pm SD & $\begin{array}{c}\text { Mean Change } \pm \\
\text { SD }\end{array}$ & $95 \% \mathrm{CI}$ & $p$-value \\
\hline \multicolumn{6}{|l|}{ Energi } \\
\hline Sebelum perlakuan & 18 & $42.14 \pm 25.42$ & $9.6 \pm 5.9$ & $5.29-24.53$ & 0.191 \\
\hline Setelah perlakuan & 18 & $51.76 \pm 40.35$ & & & \\
\hline \multicolumn{6}{|l|}{ Serat } \\
\hline Sebelum perlakuan & 18 & $1.88 \pm 1.18$ & $0.35 \pm 0.28$ & $0.18-0.90$ & 0.181 \\
\hline Setelah perlakuan & 18 & $2.24 \pm 1.49$ & & & \\
\hline \multicolumn{6}{|c|}{ Jenis Sayur per minggu } \\
\hline Sebelum perlakuan & 18 & $2.78 \pm 1.16$ & $0.056 \pm 0.27$ & $0.30-0.41$ & 0.749 \\
\hline Setelah perlakuan & 18 & $2.83 \pm 1.15$ & & & \\
\hline \multicolumn{6}{|l|}{ Jumlah Sayur (gram) } \\
\hline Sebelum perlakuan & 18 & $15.60 \pm 15.87$ & $9.13 \pm 3.74$ & $2.85-21.12$ & 0.126 \\
\hline Setelah perlakuan & 18 & $34.73 \pm 23.52$ & & & \\
\hline \multicolumn{6}{|c|}{ Jenis Buah per minggu } \\
\hline Sebelum perlakuan & 18 & $3.39 \pm 2.25$ & $0.5 \pm 0.53$ & $1.16-0.16$ & 0.132 \\
\hline Setelah perlakuan & 18 & $2.89 \pm 1.67$ & & & \\
\hline \multicolumn{6}{|l|}{ Jumlah Buah (gram) } \\
\hline Sebelum perlakuan & 18 & $47.29 \pm 31.22$ & $3.29 \pm 7.35$ & $11.45-4.86$ & 0.406 \\
\hline Setelah perlakuan & 18 & $43.99 \pm 31.38$ & & & \\
\hline
\end{tabular}

Tidak ditemukan beda yang bermakna antara jumlah energi (kkal), serat (gram), jenis dan jumlah (gram) sayur, serta jenis dan jumlah (gram) buah yang dikonsumsi sebelum dan setelah perlakuan $(p$ $\geq 0,05$ ). Namun, nilai rata-rata energi ( $m e a n=51.76$; $\mathrm{SD}=40.35$ ), serat (mean=2.24; $\mathrm{SD}=1.49$ ), jenis sayur yang dikonsumsi selama satu minggu (mean= 2.83; $\mathrm{SD}=1.15$ ), dan jumlah gram sayur yang dikonsumsi per hari (mean= 34.73; SD=23.52) setelah perlakuan meningkat jika dibandingkan dengan nilai rata-rata energi (mean $=42.14 ; \mathrm{SD}=$ 25.42), serat (mean=1.88; $\mathrm{SD}=1.18$ ), jenis sayur yang dikonsumsi selama satu minggu ( $m e a n=2.78$; $\mathrm{SD}=1.16$ ), dan jumlah gram sayur yang dikonsumsi per hari (mean $=15.60 ; \quad \mathrm{SD}=15.87$ ) sebelum perlakuan. Hal ini berbeda dengan nilai rata-rata jenis buah yang dikonsumsi per minggu (mean=
3.39; $\mathrm{SD}=2.25)$ dan jumlah gram buah yang dikonsumsi perhari (mean=47.29; $\mathrm{SD}=31.22$ ) sebelum perlakuan yang cenderung menurun jika dibandingkan dengan nilai rata-rata jenis buah yang dikonsumsi per minggu (mean $=2.89 ; \mathrm{SD}=1.67$ ) dan jumlah gram buah yang dikonsumsi perhari (mean=43.99; $\mathrm{SD}=31.38$ ) setelah perlakuan.

\section{Beda Konsumsi Buah dan Sayur Anak}

Kuesioner perilaku konsumsi buah dan sayur anak dikelompokkan menjadi dua jenis, yaitu sejumlah tujuh pertanyaan untuk sayur dan tujuh pertanyaan untuk buah. Setiap satu pertanyaan mengandung nilai minimum 1 dan maksimum 5, sehingga dalam setiap kelompok didapatkan nilai minimum 7 dan maksimum 35. Dalam uji normalitas data diketahui bahwa distribusi data normal. Hasil uji beda dipaparkan melalui Tabel 3.

Tabel 3. Konsumsi Buah dan Sayur Anak

\begin{tabular}{lccccc}
\hline \multicolumn{1}{c}{ Variabel } & N & Mean \pm SD & $\begin{array}{c}\text { Mean Change } \pm \\
\text { SD }\end{array}$ & 95\% CI & $p$-value \\
\hline $\begin{array}{l}\text { Konsumsi Sayur } \\
\quad \text { Sebelum perlakuan }\end{array}$ & 18 & $11.11 \pm 2.81$ & $1.33 \pm 0.66$ & $0.001-2.66$ & 0.05 \\
$\quad$ Setelah perlakuan & 18 & $12.44 \pm 2.75$ & & & \\
\hline $\begin{array}{l}\text { Konsumsi Buah } \\
\quad \text { Sebelum perlakuan }\end{array}$ & 18 & $17.61 \pm 6.88$ & $1.17 \pm 1.62$ & $0.78-3.11$ & 0.22 \\
$\quad$ Setelah perlakuan & 18 & $18.78 \pm 7.35$ & & & \\
\hline
\end{tabular}

Tidak ditemukan beda yang bermakna antara perilaku konsumsi sayur sebelum perlakuan dengan setelah perlakuan, begitu pula dengan perilaku konsumsi buah sebelum perlakuan dan setelah perlakuan $(p \geq 0.05)$. Ditemukan peningkatan nilai rata-rata pada kelompok nilai perilaku sayur (sebelum mean $=11.11 \pm 2.81$; sesudah mean= $12.44 \pm 2.75)$ dan nilai perilaku konsumsi buah 
(sebelum mean $=17.61 \pm 6.88 ;$ sesudah mean $=$ $18.78 \pm 7.35)$.

\section{PEMBAHASAN}

Sebanyak 18 subyek digunakan dalam penelitian. Rasio jenis kelamin subyek laki-laki dan perempuan adalah 5:4 dimana dengan rasio ini berarti hasil penelitian dapat mewakili karakteristik kedua jenis kelamin. Sebesar $88.9 \%$ ayah dan 83.3\% ibu memiliki pendidikan minimum SMA. Data ini menunjukkan bahwa jenjang pendidikan orang tua anak relatif homogen, yang berarti tingkat penerimaan informasi pada masing-masing orang tua relatif sama. ${ }^{19,20}$ Sebesar $88,9 \%$ orang tua memiliki penghasilan $\geq$ UMR, yang berarti kemampuan orang tua dalam menyediakan buah dan sayur di tingkat rumah tangga juga homogen. Sebanyak $94.4 \%$ subyek penelitian mempunyai status gizi normal. Hal ini sejalan dengan penelitian di SDN Sudirman I Makassar, yang menyebutkan bahwa prevalensi gizi lebih di Indonesia paling banyak terjadi pada anak usia $\geq 10$ tahun. ${ }^{21}$ Tidak ada perlakuan khusus kepada 5,6\% anak yang mengalami gizi lebih dalam penelitian ini, dikarenakan anak masih mengalami masa pertumbuhan.

Diduga, anak-anak akan meningkat konsumsi buah dan sayurnya setelah pemberian edukasi gizi menggunakan media buku cerita bergambar selama 8 kali intervensi dan 8 kali paparan buah dan sayur. Tabel 2 menunjukkan bahwa nilai rata-rata konsumsi energi dan serat yang dikonsumsi sebelum dan setelah perlakuan mengalami peningkatan, meskipun tidak signifikan $(p \geq 0.05)$. Hal ini sejalan dengan penelitian yang dilakukan di Belanda yang menyebutkan bahwa, 8 kali paparan merupakan frekuensi niminum anak menerima makanan yang dikenalkan kepadanya. ${ }^{22}$ Sedangkan anak akan mulai terlihat merubah kebiasaan makannya setelah paparan ke 12 sampai $14 .{ }^{23}$ Oleh karena itu, keberlanjutan edukasi gizi menggunakan media buku cerita bergambar disertai komitmen orang tua untuk menjamin ketersediaan buah dan sayur di rumah menjadi sangat penting. Peningkatan rata-rata energi untuk buah dan sayur sebesar 51.76 kkal lebih besar jika dibandingkan dengan rata-rata konsumsi buah dan sayur anak secara nasional. ${ }^{3}$ Perubahan nilai rata-rata pada variabel jenis dan jumlah buah sayur yang dikonsumsi setiap hari selain disebabkan oleh faktor intrinsik yang ada dari dalam diri anak juga dipengaruhi oleh faktor ketersediaan dan motivasi orang tua dalam menyediakan buah dan sayur di rumah. Hal ini dapat dilihat dari rata-rata jenis dan jumlah sayur yang dikonsumsi mengalami peningkatan nilai rata- rata, meskipun tidak ditemukan beda yang signifikan $(p \geq 0.05)$. Namun, jenis dan jumlah buah yang dikonsumsi mengalami penurunan nilai-rata rata dengan beda yang tidak signifikan $(p \geq 0.05)$. Diketahui bahwa dipasar, harga sayur jauh lebih murah dibandingkan dengan harga buah. Hal ini membuat sayur lebih aksessibel dibandingkan dengan buah. Sehingga diasumsikan bahwa kemampuan orang tua dalam menyediakan buah ditingkat rumah tangga masih fluktuatif.

Perilaku konsumsi buah dan sayur anak meningkat jika dilihat dari nilai rata-rata, namun tidak signifikan $(p \geq 0.05)$. Dalam teori perilaku yang dikemukakan oleh H.L Blum, perubahan perilaku dapat terjadi setelah adanya perubahan pengetahuan dan sikap. Proses ini membutuhkan waktu yang lama dengan interaksi berbagai komponen perilaku yang kompleks. ${ }^{11,24}$ Peningkatan nilai rata-rata konsumsi buah dan sayur anak yang diperoleh dari hasil wawancara responden menggunakan CEBQ, diasumsikan disebabkan karena adanya perubahan pengetahuan dan sikap anak terhadap buah dan sayur setelah dilakukan edukasi gizi menggunakan media buku cerita bergambar selama 4 minggu. Edukasi gizi menggunakan media buku cerita bergambar memungkinkan anak untuk memproses informasi dari aspek kognitif dan afektif, yang memungkinkan terjadinya perubahan pengetahuan dan sikap yang lebih cepat dibandingkan dengan metode lainnya. ${ }^{25}$ Aspek kognitif memungkinkan anak untuk secara langsung menghubungkan informasi baru dengan jalannya cerita dan skema karakter cerita, sedangkan dari aspek afektif anak yang diberikan edukasi melalui buku cerita bergambar akan memiliki perasaan yang positif terhadap buah dan sayur. ${ }^{26,27}$ Jumlah asupan dan penerimaan anak terhadap buah dan sayur juga disebabkan oleh faktor biologis, budaya, lingkungan, pergaulan, dan faktor sosial. ${ }^{28}$

\section{SIMPULAN}

Edukasi gizi menggunakan media buku cerita bergambar meningkatkan konsumsi buah dan sayur anak, namun tidak signifikan. Dukungan dari orang tua dan guru mutlak diperlukan untuk menjamin ketersediaan buah dan sayur di tingkat rumah tangga dan meningkatkan pengetahuan serta motivasi anak dalam mengkonsumsi buah dan sayur.

\section{SARAN}

Perlu dilakukan upaya yang bersifat multisektoral untuk menjamin ketersediaan buah dan sayur di tingkat rumah tangga. Sehingga, ketika pengetahuan dan sikap anak terhadap buah dan 
sayur meningkat, perubahan konsumsi buah dan sayur anak juga meningkat karena akses terhadap buah dan sayur di rumah mudah.

\section{DAFTAR PUSTAKA}

1. Geller, K.S. \& Dzwaltowski, D.A. Longitudinal and Cross-sectional Influences on Youth Food and Vegetable Consumption. Nutrition Review 2009: Vol.67, No.2, 65-76

2. Ocke, M.C., Van Rossum, C.T.M., Fransen, H.P.,Buurma, E.M., De Boer, E.J., Brants, H.A.M., et al. Dutch National Food Consumption Survei Young Children 2005/2006. Bilthoven, Netherlands: 2008. Report No: 350070001

3. Survei Sosial Ekonomi Nasional (SUSENAS). Rata-rata Konsumsi per kkal Tahun 2007 sampai 2014 Menurut Jenis Bahan Makanan. Badan Pusat Statistik Indonesia. Diakses melalui http://www.bps.go.id tanggal 18 April 2014

4. Cooke, L.J., Wardle, J., Gibson, E.L., Sapochnik, M., Sheiham, A. \& Lawson, M. Demographic, Familial, and trait Predictors of Fruit and Vegetable Consumption by Pre-School Children. Journal of public Health Nutrition 2003: Vol.7, No.2, 295-302

5. Savage, J., Fisher, J.O., \& Birch, L. Parental Influence on Eating Behavior: Conception to Adolescence. Journal of Law, Medicine, \& Ethics 2007: Vol.35, No.1, 22-34

6. Patrick, H. \& Nicklas, T.A. A Review of Family and Social Determinants of Children's Eating Pattern and Diet Quality. Journal of the American College of Nutrition 2005: Vol. 24, No.2, 83-92

7. Badan Pusat Statistik. Pertanian dan Pertambangan: Prosuksi Sayuran di Indonesia 1997-2013. Badan Pusat Statistik Republik Indonesia. Diakses melalui http://www.bps.go.id/tab_sub/view.php?kat=3\&ta bel=1\&daftar=1\&id tanggal 13 April 2014.

8. Badan Pusat Statistik. Perkembangan Beberapa Indikator Utama Sosial-Ekonomi Indonesia: Pengeluaran Konsumsi. Badan Pusat Statistik Republik Indonesia: Sensus Pertanian 2013

9. Eliassen, E.K. The Impact of Teachers and Families on Young Children's Eating Behaviors. National Association for the Education of Young Children. 2011

10. Pepino, M.Y. \& Manella, J.A. Factors Contributing to Individual Differences in Sucrose Preference. Chemical Sense 30 (Suppl. 1), i319-i320: 2005

11. Swadener, S.S. Nutrition education for Preschool Age Children. A Research Review. Journal of Nutrition Education and Behaviour. 27 (6), 291 297: 2005

12. Contento, I.R. Nutrition Education: Lingking Research, Theory, and Practice. Sudbury, Canada: Jones and Bartlett Publishers; 2007

13. Moyer-Guse, E. Toward a Theory of Entertainment Persuasion: Explaining the Persuasive Effect of Entertainment Education Messages. Journal of Communication Theory 2008: 18, 407-425

14. Singhal, A., Cody, M.J., Rogers, E.M., \& Sabido,
M. Entertainment Education and Social Change. History, Research, and Practice. Eds. Mahwah, NJ, Erlbaum: 2004

15. Moyer-Gusé, E., \& Nabi, R. L. Explaining the Effects of Narrative in an Entertainment Television Program. Overcoming Resistance to Persuasion. Human Communication Research 2010: 36, 26-52.

16. Buijzen, M., Van Reijmersdal, E. A., \& Owen, L. H. Introducing the PCMC Model. An Investigative Framework for Young People's Processing of Commercial Media Content. Communication Theory 2010: 20, 427-450.

17. Bellows, L. \& Anderson, J. The Food Friends: Encouraging Preschoolers to Try New Foods. Nutrition and physical fitness, 1-3: 2006

18. Niemeier, B.S., Tande, D.L., Hwang, J., Stastny, S. \& Hektner, J.M. Using education, Exposure, and Environments to Increase Prescool Children Knowledge about Fruit and Vegetables. Journal of Extension. Vol.48 No.1 Page. 1-5: 2010

19. Deforges, C. \& Abouchaar, A. The Impact of Parental Involvement, Parental Support, and Family Education on Pupil Achievements and Adjusment: A Literature Review. Department for Education and Skills, Nottingham: UK. 2003

20. Davis-Kean, P.E. The Influence of Parent Education and Family Income on Child Achievement: The Indirect Role of Parental Expectation and the Home Environment. Journal of Family Psycology, 2005. Vol.19, No. 2, 294-304

21. Thasim, S., Syam, A., \& Najamuddin, U. Pengaruh Edukasi Gizi Terhadap Perubahan Pengetahuan dan Asupan Zat Gizi pada Anak Gizi Lebih di SDN Sudirman I Makassar. Artikel Penelitian. Program Studi Ilmu Gizi Fakultas Kesehatan Masyarakat Universitas Hasanuddin Makassar. 2013

22. Bellows, L. \& Anderson, J. The Food Friends: Encouraging Preschoolers to Try New Foods. Nutrition and physical fitness, 1-3: 2006

23. Niemeier, B.S., Tande, D.L., Hwang, J., Stastny, S. \& Hektner, J.M. Using education, Exposure, and Environments to Increase Prescool Children Knowledge about Fruit and Vegetables. Journal of Extension. Vol.48 No.1 Page. 1-5: 2010

24. Contento, I., G.I Balch, S.K.Y.L Bronner. The Effectiveness of nutrition Education and Implications for Nutrition Education Policy, Programs, and Research. A Review of Research. Journal of Nutrition Education. 27(6), 279-418: 2000

25. De Droog, S.M., Buijzen, M., Valkenburg, P.M. Enhancing Children's Vegetable Consumption Using Vegetable-promoting Picture Book: The Impact of Interactive Shared Reading and Character-product Congruence. Elsevier Journal, Appetite, 73, 73-80: 2014

26. Fisch, S.M. A Capacity Model of Children's Comprehention of Educational Content on Television. Journal of Media Psycology, 2000. Vol.2, 63-91 
27. Institute of Medicine. Food Marketing to Children and Youth: Treat or Opportunity? Washington, DC: National Academies Press. 2006

28. Contento, I.R. Nutrition Education: Lingking Research, Theory, and Practice. Sudbury, Canada: Jones and Bartlett Publishers; 2007 